\title{
The role of organizations of the non-profit sector in the employment of people disadvantaged in the labour market in Slovakia
}

\begin{abstract}
The Slovak Republic is currently experiencing a period of historically low registered unemployment. On the other hand, the long-term unemployment rate and participation of disadvantaged groups in the labour market has for a long time been showing alarming values. Several countries have responded to the challenges associated with employment of disadvantaged groups by intensive and systematic involvement of non-public sector, specifically non-governmental organizations (NGOs), either in the role of employment services providers or employers. The possibility to involve NGOs in providing public employment services (PES) intended for groups farthest from the labour market is starting to be considered also in Slovakia. In this debate, however, there are also opinions that doubt the capacity of the NGO sector in Slovakia in connection with employment increase of disadvantaged groups. This article, therefore, seeks to describe the roles that NGOs are playing in the field of employment of disadvantaged groups in Slovakia.
\end{abstract}

Key words: employment of disadvantaged, NGOs, public employment services

1 Correspondence: Institute for Forecasting, Šancová 56, Bratislava 811 05, Slovak Republic, author's email address: polackova.zuzana@savba.sk. 


\section{Introduction}

According to the data from the Central Office of labour, social affairs and family of the Slovak Republic (ÚPSVaR), the rate of registered unemployment at the end of the year 2019 in the Slovak Republic reached 4.92\% (ÚPSVaR, 2019), which can be considered a historical minimum. However, structural unemployment remains a question, which is reflected in the form of high long-term unemployment, major regional disparities or low participation of selected groups in the labour market. The proportion of the long-term unemployed in the total number of unemployed does not change from year to year and reaches the second highest value in the countries of the EU (58.9\% by the end of 2019) ${ }^{2}$.

Employment rates of people farthest from the labour market, represented for the purposes of this article by people from the marginalized Roma communities (MRC) and people with disabilities, remains a challenge. The employment rate of the Roma population in 2018 was $21 \%$ according to the estimates (compared with $51 \%$ in the majority population living in the same municipalities) (IFP, 2019); the employment rate of people with disability according to the estimates in the year 2017 reached $38.7 \%$ (in comparison with the total level of employment, which was 71.1\% in 2017) (Polačková, 2018). In spite of the low values, the figures above represent a slight progress compared to the previous period. However, it has to be viewed with caution, as it is rather the result of economic growth and current work-force shortage that employers are suffering from, than the result of systematic support of the job-seekers' capacities.

Regarding the access of disadvantaged groups to the labour market and the high long-term unemployment, attention is drawn to issues of quality and the means of public employment services provision (Kalužná, 2008; Kuddo, 2009). The quality of public employment services and their limited capacities to increase the employment rate/ employability of the most disadvantaged groups has been at the centre of the discussions for a long time. Inability of PES provided by public labour offices to increase capacities of large-group of long-term unemployed ended in the situation in which every third newly created job in Slovakia in the year 2018 was filled by a foreign worker (IFP, 2019).

The quality of the currently provided PES in regards of the employability increase of the long-term unemployed is in the centre of the interest not only among the employers, but also European Commission. The European employment strategy it requests that the individual member states modernise and strengthen institutional capacity of employment services and regularly evaluate the efficiency of the implemented programs. Increasingly, more countries admit that the traditional labour offices do not have sufficient capacity needed to ensure the provision of services for groups farthest from the labour market and they are seeking for new models of PES provision or for other methods aiming employability/employment increase of disadvantaged groups. Still more countries are gradually involving non-public service providers, specialized to work with the individual target groups, into the provision of PES and other public services. More broadly, the role of the governments traditionally being a key provider of public services is moving

2 Eurostat (lfsq_upgal). 
to governance, where the state attempts to "steer" or "regulate" economic activities (including PES provision) through co-opting non-governmental actors (Hutter, 2006). This trend also redefines the paradigm of public services as "services funded by the public purse, rather than necessarily delivered by the public sector" (Blair in Davies, 2008).

Growing use of non-public providers of employment services is not new; e.g. it has been a key part of the welfare reform in UK introduced by Cabinet of T. Blair (Davies, 2008). However, this development if not confined to UK, similar initiatives took place in several other countries. An illustration of a successful model of involving non-public service providers in employment services is Australia, where the provision of public employment services is fully realized through non-public providers, a large part of which are non-governmental organizations (NGOs) (OECD, 2012). The service providers are financially motivated to provide their services in the most efficient manner since payments by the state for services rendered combine components for the service and for success in the placement of clients and keeping them in employment. The amount of the payment is based on the situation of a specific client. The payment for placing and keeping a client who is more distant from the labour market is higher than for a client with easier profile. The basic division of employment services in Australia is currently determined by two programs, one intended for the general group of job seekers (JobActive), in which approximately 1600 service providers are currently involved and one for applicants with disabilities (Disability employment support services), in which, according the official data published by Australian Government, approximately 3500 providers are involved.

The experience of some countries, where the provision of public employment services includes also NGO involvement (e.g., the Netherlands, the UK) shows that the model may have a positive impact, except on increasing of employment services quality, also on promoting stability of the non-profit sector in the country. For example, the adoption of the model in the UK was communicated as the intention of government to "to develop the relationship with the voluntary sector" and in 1998 the Compact was published by the Home Office setting out how the two should work together. Later, in 2005, the Labour Party manifesto declared that "the voluntary and community sector has shown itself to be innovative, efficient and effective. Its potential for service should be considered on equal terms" (Davies, 2008). High recognition of the NGOs role in the service provision (backed with the access to necessary financial resources), in a fact, strongly encouraged the whole sector to play a vital and confident role in the society (Brown, 2006).

A condition is that the involvement is based on long-term contracts (of min.3 years), for which the NGOs may apply in transparent tenders and which provide a stable and fair cooperation between government, public authorities and NGOs in regards of PES provision. (OECD, 2012). In the mentioned framework, NGOs are moving from the position of grant applicants (which is the most frequent source of funding for NGOs in many countries) to the position of a service provider, whose financial claims are contractually enforceable. Such change of paradigm may substantially contribute to the financial stability of the involved NGOs, so they can invest in their capacity building and significantly influence quality of the entire NGO sector in the country. In the same time 
period as Australia and the UK started to experiment with the systematic involvement of NGOs in the provision of public employment services, the International Labour Organization issued the so-called Private Employment Agencies Convention No. 181 of 1997, through which it encourages the individual countries to involve non-public service providers in the provision of employment services as well. Despite the fact that the Slovak Republic has ratified the Convention as late as 2010, the first experience of involving NGOs has been gained in the years 2000-2004. In this period, a pilot model of supported employment for people with disabilities implemented by the National labour office ${ }^{3}$ in cooperation with selected NGOs was tested. Co-operation was accomplished based on a contractual relationship and clearly defined conditions, including financial remuneration, which was conditional upon achievements of the organization.

For non-profit organizations in Slovakia, it was one of the first opportunities to become involved in providing public services as such and act as full-fledged partners to the organisation of the public administration. This strongly contributed to professionalisation and self-recognition of the involved organizations and motivated other organizations to join. The involved organizations even initialized the founding of their umbrella organization, which represented their interests and pursued capacity building in the area of supported employment.

However, the cooperation between the National labour office and involved NGOs was limited by the duration of the project and after depletion of the funds, the National labour office was unable to provide additional resources necessary to maintain (or extend) the initiated cooperation despite its successful results. The model was not restored in the subsequent period either and the established network of supported employment gradually disintegrated. The involved NGOs subsequently used the acquired capacity for direct employment of people from disadvantaged groups and based on the contributions from active labour market policies (ALMPs), they shifted their focus and started to act as employers of people from disadvantaged groups. Given the steadily high long-term unemployment rate, the low employment rates of the most disadvantaged groups, and the international trend in PES provision, questions related to the involvement of non-public providers (specially NGOs) in the provision of public employment services for the most disadvantaged groups, have started to appear repeatedly in the public debate also in Slovakia. The need for innovative approaches in employment services for the most disadvantaged groups is clear. There is a strong consensus that part of the services could be provided by NGOs specialised to work with the people from variety of disadvantaged groups and the cooperation could be based on a multiple-year contract. However, it is not clear whether the NGO scene in Slovakia is currently prepared and able to provide employment services in the expected range and quality. Given the missing quantitative data on the NGO sector in Slovakia, it is also not clear what role the NGO sector plays in connection with employment of the most disadvantaged groups per se. The international

${ }^{3}$ National labour office was later transformed to the Central office of labour, social affairs and family. 
debate about the NGOs involvement in the public services provision (including PES) is very vivid (Macmillan, 2010). It explores a variety of questions related e.g.to the quality assessment of the services provided by different actors or impact on the client.

It is important to note, that the aim of this article in not to assess the quality of services provided by NGOs or outcomes for service users. The article rather aims to discuss about the capacities of the Slovak NGOs to impact on the issues of employment of people from disadvantaged groups. Despite the high potential and impact on the NGOs sustainability, PES provision and job brokering is only one of the roles the NGOs may take. The aim of this article is to explore the roles that the NGOs are playing in the area of employment of people disadvantaged in the labour market and to describe the tasks that the NGOs currently are performing in this area in Slovakia.

\section{Methodology}

This article is based, to a large extent, on qualitative research conducted in the second half of the year 2017, in which the main research question was formulated as follows:

Are non-governmental non-profit organizations a suitable alternative to labour offices and other established public organizations in matters of provision of public employment services and increasing employment of people disadvantaged in the labour market? ${ }^{4}$

During the qualitative research, 12 semi-structured interviews were conducted with representatives of NGOs that specialise in working with people from the individual disadvantaged groups. In all the organizations, the area of employment/employability is only one from the wider spectrum of support that they provided to their clients. A number of the interviewed organizations have direct experience with employment of difficult to employ persons, while others concentrate more on facilitating employment or supporting the capacities required for the labour market.

Seven of the interviewed respondents have been identified based on their expertise and their visibility in the employment/employability area (whether in the media or professional public). To identify other respondents, snowball sampling was applied, in which the already involved respondents identified other potential respondents. When identifying the NGOs for the interviews, the specific legal form of the organizations was not considered; representatives of civil associations and non-profit organizations providing public services as well as a representative of a foundation were interviewed.

Research interviews with the representatives of the NGOs were preceded by 4 semi-structured interviews with representatives from the Central office of labour, social affairs and family of the Slovak Republic, local office of labour social affairs and family, Ministry of Labour, social affairs and family, and academia.

${ }^{4}$ Please note that the formulated research question was central for the mentioned research, the presented article utilizes the data collected during the research, however, the central question of this article differs. 
For better illustration of the situation, publicly available administrative data collected by the Central office of labour, social affairs and family, the Ministry of Interior of the Slovak Republic, and the Financial Administration of Slovak Republic were analysed as well. Data collected via the interviews were, thereafter, confronted with the administrative data.

\section{The NGO sector in Slovakia and employment/employability of disadvantaged groups}

At the end of the year 2018, approximately 58000 NGOs were registered in Slovakia 5 (EC, 2020). Given the inconsistency of the available information, it is not possible to unambiguously state how many of the registered organizations are active or what kind of public interest service activities they provide. Likewise, quantifying the representation of the various types of public interest service activities in the NGO sector in Slovakia is extremely complicated, as one organization may be providing several types of public interest service activities, or identical action can also be implemented pursuant to multiple types of public interest activities and these can overlap. Therefore, we are currently unable to determine the percentage of the registered NGOs dealing with the areas of employment and employability of the disadvantaged groups. Based on the information from the register of non-profit organizations providing public benefit services (which is one of the legal forms of NGOs) published by the Ministry of Interior of the Slovak Republic it is possible to conclude that approximately $30 \%$ of the total 3,3776 organizations registered in the form of non-profit organization providing public benefit services list providing activities in the field of employment in their statutes. However, this data is not reliable because we do not know how many of these organizations actually provide these services, nevertheless none of the research respondents would estimate, that the number of NGOs active on the field of employment of people disadvantaged on the labour market it higher than 100 .

Despite the lack of exact information on the thematic breakdown of the NGO sector, relatively accurate information on the regional representation of registered NGOs exists. It is notable that there is no clear correlation between the registered unemployment rate (see Map 1) 7 and the number of district inhabitants per registered NGO (see Map 2) ${ }^{8}$. Based on the administrative data, it is possible to claim that southern districts, which are characterised by high rate of registered long-term unemployment, show high intensity of presence of registered NGOs per number of adult inhabitants ${ }^{9}$.

5 By legal forms, these are civil associations, non-profit organizations providing generally beneficial services, foundations, non-investment funds and organizations with international element.

6 Figure from the year 2018.

7 Legend to Map 1: the darker the coloration, the higher the rate of registered unemployment.

8 Legend to Map 2: the lighter the coloration, the lower the number of adult district inhabitants per one registered NGO.

9 For example in the Rožňava District, the registered unemployment rate as of 31/12/2018 was 13,92\% and there were 113 people per one registered NGO in 2017. 


\section{Map 1}

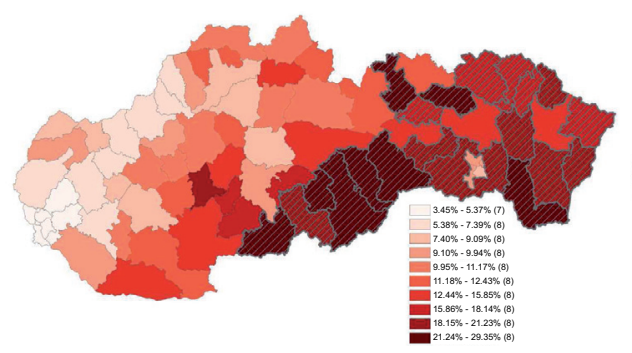

Map 2

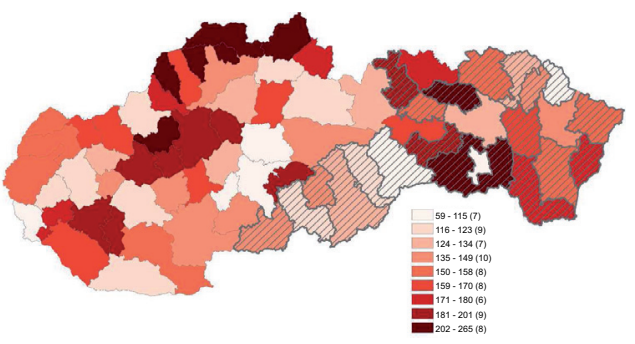

Source: Polačkova, 2019.

The regional distribution of NGOs in Slovakia also does not support the assumption of the so-called institutional void (Mair and Martí, 2009) in the most underdeveloped districts (marked on the maps with hatch pattern). It indicates the absence of modern institutions, including NGOs, which are a prerequisite for the improvement of socio-economic status of disadvantaged groups of people.

Even in the district with the lowest density of NGOs, there are 265 adult inhabitants per a registered NGO (Polačková, 2019), therefore, it is possible to conclude that NGOs are present throughout the entire area of Slovakia and their density is adequate. Number of registered NGOS, however, reveals nothing about their quality or the range of their implemented activities. Given the above, it can be argued that it is currently not possible to quantify the capacity of the NGO sector in the area of employment/employability of disadvantaged groups and the situation can be illustrated based mainly on qualitative information.

Based on the findings in the field, activities of NGOs in Slovakia can be divided into three main categories in connection with the employment of disadvantaged groups:

- NGOs as employers of the disadvantaged groups,

- NGOs as intermediaries of employment,

- NGOs as advocates of interests of groups that are difficult to employ in connection with their entrance/remaining in the labour market.

\section{NGOs as employers of disadvantaged groups ${ }^{10}$}

Despite the fact that some of the respondents interviewed during the research perceive the role of the NGOs primarily in the creation of jobs and employment of people distant from the labour market, based on the analysis of the administrative data, it is possible to state that the share of NGOs in the employment of the target group is not significant in Slovakia.

10 For the purposes of this article, disadvantaged groups are primarily represented by people with disabilities and people from the marginalized Roma communities. 
As one of the respondents ${ }^{11}$ stated

general public stereotypically consider NGO sector to be the main employer of people with disabilities. It can be assumed that the mentioned stereotype is based on the conviction that people with disabilities work predominantly in the sheltered workshops, as it was in the past ${ }^{12}$, and these are considered to be exclusively an initiative of NGOs.

The analysis of the administrative data does not confirm the assumption about the lead role of NGOs in the starting and managing sheltered workshops. According to the data from the Central office of labour, social affairs and family, 1704 sheltered workshop were registered as of 31/12/2019 in Slovakia, but only 199 of them were of an NGO legal form. The number of employees of sheltered workshops established by NGO was 755 persons, compared to 4,586 employees employed by business entities. Thus, NGOs are representing only approximately $16 \%$ of the jobs for people with disabilities created by sheltered workshops. However, on the basis of the statistical data, it is possible to conclude that only $11 \%$ of people with disabilities active in the labour market work in sheltered workshops or sheltered work places; most of them are in the conditions of the open labour market (Polačková, 2018), thus sheltered workshops established by NGOs are employing only some $2 \%$ of all people with the health disability active on labour marketAn interesting fact is that legal forms of NGOs do not dominate among registered social enterprises in Slovakia either. As one of the respondents, the social entrepreneur active in Roma employment, stated:

I am shocked by the low numbers of NGOs in the register of social enterprises. ${ }^{13}$

In 2018, Act on social economy and social enterprises ${ }^{14}$, which has brought a legal definition of social enterprise, was adopted in Slovakia. One of the categories of social enterprises is the work-integration social enterprise, which meets its positive social impact goal through employment of people distant from the labour market. A general expectation was that NGOs would be the main protagonists of social enterprises implemented pursuant to the adopted Act.

So far, however, this assumption has not been justified, as out of 66 registered social enterprises (as of 31/12/2019), as many as 5915 of them had the legal form of a limited liability company with no affiliation to NGOs. Thus, the role played by NGOs is rather marginal in this field as well.

11 Research Interview No. 9 - local NGO focused on the work with the people with disability, also employer.

12 Before the 1990, people with health disability were the most often placed in the segregated work environment.

13 Research Interview No. 2 - NGO, also registered social enterprise, specialized on employment of people from Roma origin.

14 Act 112/2018 Coll. on social economy and social enterprises.

15 See the register of social enterprises maintained by the Ministry of labour, social affairs and family of the Slovak Republic. 
The respondent from academia sector interpreted this situation by the lack of entrepreneurial capacities in the NGO sector, saying

those from the NGO sector are predominantly focused on the fulfilling the social aims in the cost of entrepreneurial element. With such a mindset you are not able to formulate any sustainable business plan and perform based on the entrepreneurial principles. The NGO sector needs more people from the business sector... ${ }^{16}$

Similarly, small representation of NGOs can be seen among the applicants for contribution intended for new job creation, which is realized pursuant to an active labour market policy. Within the reported measure ${ }^{17}$, which has been identified as a measure with the most distinctive opportunities for applicants from the NGO sector, only approximately 5\% of the applicants in the years 2016-2018 were from the NGOs sector ${ }^{18}$.

All three of the analysed instruments (i.e. sheltered workshops, work integration social enterprises and active labour market measure pursuant to Article 54 of Act on employment services) are part of active labour market policies and it is possible to obtain financial support for the creation (in some cases also maintaining) of jobs. Based on the conducted interviews, it can be concluded that the possibility to receive a financial contribution from ALMP plays a decisive role in the case of people furthest from the labour market. These are usually employees, who are unable to provide adequate work performances immediately after starting the employment and the length of their adaptation process is often several months. Financial contribution allocated for the subsidy of their wages is therefore key and it may be expected that the employment of this target group outside of the scope of ALMPs is limited.

...without the subsidy, we would not be able to employ anyone. The productivity of our employees is low, our aim is their work integration and social integration. For the first few months, we are focused on improvement of the basic work habits and social skills, productivity is the minor focus... ${ }^{19}$

Low participation of NGOs in the role of an employer of people distant from the labour market can be interpreted also by a concern of NGOs to fulfil all obligations arising from an employer-employee relationship, since a possible failure to fulfil the obligations is judged relatively strictly by the inspection authorities in Slovakia. The problem is the financial stability of NGOs in Slovakia, which is extremely vulnerable and NGOs are usually unable to secure financial resources necessary for co-financing (in case they

16 Research Interview No. 14 - respondent from academia specialized on issues related employment.

17 The measure is implemented pursuant to Article 54 ,programs and projects”, in which it is possible to obtain financial support for the creation of a new job filled by a certain category of registered employment applicants.

18 UPSVaR Statistics.

19 Research Interview No. 4 - NGO, registered social enterprises, specialized on the employment of people with intellectual disability. 
receive the contribution from ALMP) or full funding of wages and other costs related to employment.

...we are in an absurd situation. On one hand we need help in our organisation and we would be able to create a job for one low-skilled person. But we are eligible to apply only for the subsidy which requires a further sustainability of the jobs paid from the internal resources of the employer. If you fail in this sustainability, you have to pay a fine. We are project based and do not know what will come next month. I simply can not commit the organisation for such pledge. Thus, we are hiring for short term contracts, but those who need the work the most are not interested in short term contracts, because it is risky for their social benefits. Thus, at the end, instead of employing the most needy, we are giving a short time jobs to those who are at disposal. ${ }^{20}$

\section{NGOs as intermediary of employment for people from disadvantaged groups}

Despite the fact that in Slovakia, there is no model of systematic involvement of NGOs in free -of-charge employment brokering for the most vulnerable groups, during the interviews with the NGOs, activities aimed precisely at employment brokering and employment facilitation for people with whom the organization was working were often mentioned.

...the core of our activities is to help people to get a job at the open labour market. The most important is to provide our clients with information and to help them to understand their capacities...21

NGOs often serve as references for the employers and it is not exceptional that employers contact a specific NGO with a request to find suitable employees.

...we are often approached by employers who are seeking workforce. They know that candidates recommended by us are mostly the good ones. The main reason behind our good choice is our ability to assess the client's real interest, and it is because we know their family and personal situation. ${ }^{22}$

Several NGOs also actively establish contacts with employers and offer them the skills and capacity of their clients. These NGOs are de facto in the position of job intermediary or work agencies; however, they usually do not receive financial compensation for these activities, and they perform them as volunteers. The business sector often operates under the misconception that services of NGOs do not need to be paid, as NGOs are automatically financed through grants. Several interviewed representatives of NGOs reported that the business sector appreciates the cooperation with NGOs very much, but only until the moment when the business sector should start to pay for the services of

${ }^{20}$ Research Interview No. 12 - local NGO operating the lagging region.

${ }^{21}$ Research Interview No. 1 - regional based NGO working in marginalized Roma communities.

22 Research Interview No. 5 - local NGO, also employer, working with young adults of Roma origin. 
the NGOs. At that moment, the companies often turn to entities registered as businesses because they believe that a business entity is more specialised, and it is therefore in order to pay for its services, even in cases when services provided by NGOs are of better quality.

...we piloted a small social enterprise, something like a job-brokering business for disadvantaged job seekers. Employers from business sector (our clients) were and are happy to cooperate and approach us. But when it comes to the payment... it is kind "of magic kingdom"... The sentence I usually hear is "but you have money from some foundation, don't you!" or "well, I do not have a budget for this, this year budget is fully allocated for the purpose of the cooperation with the job agencies we are working with". To hear this makes me crazy. ${ }^{23}$

Only in exceptional cases have NGOs the status of an agency of temporary employment ${ }^{24}$, i.e. the status of an entity the employers are used to paying for its services. NGOs more often act in the position of agencies of supported employment, however, as stated in the introduction of this article, in the case of agencies of supported employment, there is no systematic support from the state. Therefore, a significant majority of the agencies of supported employment do not function and the number of organizations providing supported employment services without a contribution from the state is estimated at less than five.

Agencies of supported employment cannot rely on payments from employers for placement of an employee, as agencies of supported employment are largely focused on activating clients and support of their social skills. Based on the estimate of respondents interviewed, even from the most successful agencies, only about $30 \%$ of the clients are placed and maintained in the labour market in Slovakia. The main source of their financing is variety of foundations and private donors, occasionally the public contribution for social services. However, the financial resources are extremely scarce, and the existing agencies very much rely on the work of volunteers.

The state attempts to substitute the absence of a functional mechanism aimed at financing activities of supported employment by demand-oriented calls for project proposals co-financed by the ESF. Since the beginning of the programming period (2014) two such calls were announced, however, both ended in a fiasco and both cases, only approximately $4 \%$ of the total amount allocated was used. The main reason behind was the unacceptably set conditions, which presented a high degree of risk for the NGOs.

... although we are in a permanent need for money, we decided not to apply. We assess all cons and pros and the criteria were ultimately unfavourable for the project applicants ${ }^{25}$

23 Research Interview No. 1 - regional based NGO working in marginalized Roma communities.

${ }^{24}$ From the total number of 470 active temporary employment agencies, only 2 are NGOs. A reason for low representation is mainly the amount of the financial guarantee (EUR 30 000), which an organization applying for the statute of temporary employment agency must have at its disposal.

25 Research Interview No 10. - local NGO working with people with disabilities. 
However, another problem is the lack of interest from NGOs to apply for ESF support allocated through demand-oriented projects due to negative experiences with utilizing similar support in the past.

...we submitted the project, went through the kind of crazy process, won the support, but when I got to the agreement to sign, I gave up. To implement a project was too risky for us... ${ }^{26}$

NGOs as advocates of interests of disadvantaged groups in the context of their entrance into/remaining in the labour market

A unique role that NGOs fill in connection with the employment of disadvantaged groups in Slovakia is of advocacy nature. It is not fundamental in its range but is important in its significance. NGOs are often the only entities, which highlight the presence of disadvantaged groups, the low level of their participation in the labour market and the existence of structural barriers preventing their entry onto the labour market. NGOs perform these tasks often with the support of international organizations, which commission the NGOs to prepare shadow reports on implementation of government strategies resulting from international conventions ${ }^{27}$.

The implementation of advocacy activities is expensive and technically demanding and is conditional on the presence of available financial resources. However, these are not automatic in Slovakia, therefore, advocacy activities in relation to the area of employment/ employability of disadvantaged groups are implemented only on project basis and only sporadically.

Nevertheless, it is possible to include activities focused on sensitization of the public to employees from disadvantaged groups among advocacy activities. According to a survey of discrimination in the EU from the year 2019 (EC, 2019), 15\% of Slovaks indicated that to have a colleague from a Roma ethnicity is an absolutely uncomfortable situation for them, and in case of acceptance of a colleague with disabilities, 7\% answered that they consider such a situation absolutely uncomfortable.

...what I see in the practice is lack of information. In fact, I believe that employers are not opposing the employment of people with disabilities as such. The problem is lack of information about examples of good practice. Employers are hesitant to accept job-seekers with health disability, because they do not know what it means and what are the needs of an employee with disability... We urgently need to advocate and share the information. I see need but we do not have any spare resources, we are totally overwhelmed with the daily operation... 28

According to several statements, colleagues and the pleasantness/unpleasantness of the working environment are the main determinants for persons distant from the labour

26 Research Interview No. 3 - national NGO working with people with disabilities.

27 e.g. National strategy for Roma Integration or UN Convention on the rights of Persons with Disabilities and others.

28 Research Interview No. 3 - national NGO working with people with disabilities. 
market of whether they will remain in work. Therefore, several NGOs are beginning to implement training programs aimed at influencing the attitudes of colleagues of persons distant from the labour market toward them. Based on the compiled information, it is possible to conclude that training in the field of diversity management in Slovakia is currently done exclusively by NGOs.

...we helped one company to hire in marginalized Roma communities. People were happy to get a job. Their motivation seemed to be high as well. However, we experienced high turnover. People got the job and in 3-4 days, they dropped the job. When we were searching for the reasons, we found that Roma employees did not have a feeling of being welcome in the workplace. So we proposed the sensitisation training for shift leaders. I would say that it was rather a "mutual psychotherapy". We found out that shift leaders are also very frustrated by the whole situation and the training was the first ever opportunity to speak and ask openly. The impact of the training was highly surprising, the dropout after the training was much lower. ${ }^{29}$

\section{Conclusion}

The NGO sector, despite the fact that it often acts as an advocate for disadvantaged groups and realizes many important activities in the area of inclusion of disadvantaged groups, it currently does not have a significant position in the area of employment of disadvantaged groups in Slovakia. Activities aimed at facilitation of employment and job brokering are of sporadic nature and are more a result of personal commitment of a particular NGO than of any coherent strategy, which would be specific to the NGO sector. Same can be concluded in regards of other two roles the NGOs plays on the field of employment of disadvantaged groups - the direct employing and advocating. The main reasons are poor financial stability, limited access to the resources, unfavourable conditions in the project bids or absence of governmental strategy for involving NGOs to public services provision.

It is difficult to provide a clear answer to the question of capacity and preparedness of the NGO sector to respond to the possible transformation of public employment services realized by the systematic involvement of NGOs in the provision of public employment services based on a contract between PES and a specific NGO. Several respondents, specially, those representing labour offices, expressed doubts about the current preparedness of NGOs to operate as a confident provider of employment services, but in the same breath claimed that the capacity of NGOs has been decimated due to the absence of such models and the absence of systematic support of NGOs by the state. Through the experience from the time period 2000-2004, when a functional network of agencies of supported employment was established and operated, several respondents argued in favour of a hidden and underutilized capacity of NGOs, which would mobilise and develop if a similar model existed. Therefore, in connection with the possible introduction of the model of NGOs involvement to PES provision, it is necessary to adopt a gradual approach and to implement it preferentially in areas where it is possible

${ }_{29}$ Research Interview No. 1 - regional based NGO working in marginalized Roma communities. 
to presume the presence of well-established organizations. Also, based on the experience from the time period 2000-2004, it can be anticipated that the implementation of the program with a small number of organizations would create a snowball effect and other organizations would start to mobilise their currently dormant capacity and would join in gradually.

Assessing the capacity of the NGO sector in connection with employment of disadvantaged groups in a situation when the state does not create conditions for financial stability of the NGO sector, is also difficult. Unemployment of individuals from disadvantaged groups is often not a result of lack of interest of the particular individual, but rather is conditional on the presence of many structural obstacles, the overcoming of which requires a comprehensive approach and active involvement of many stakeholders. Therefore, the low participation of NGOs in the positions of employers of people distant from the labour market and statistically low participation of NGOs in the activities related to the topic of employment/employability may not necessarily indicate only the capacity of NGOs but can also be a statement of (non)existence of support network focused on overcoming structural obstacles and (non)participation of other stakeholders.

It may be concluded, that the roles that NGOs are playing in the area of employment of people disadvantaged on the labour market may be clustered to the three categories i) direct employment and job creation, ii) job brokering and job facilitation and iii) advocacy. In regards of direct employment, or the job facilitation, the tasks performed by NGOs are not statistically significant and in the wider context are rather invisible. NGOs are not recognized as a noticeable employer in terms of size, they are rather recognized as advocates for people disadvantaged on the labour market. The reasons are primarily in the financial instability of the NGOs active on the field of employment in Slovakia caused by absence of governmental strategy for involving NGOs to public services provision. On the other hand, the past experience with the involvement of NGOs to the provision of supported employment services and several other examples of current activities are suggesting the uncovered potential that NGOs in Slovakia active on the field of employment of people disadvantaged on the labour market may deliver once the conditions would allow.

\section{Disclaimer}

This paper was supported by the project APVV-17-0141 Analysis of Barriers in Access to Employment for Marginalized Groups of Population.

\section{References}

Brown, G. (2006). Spending Review in 2007 Will Identify Priorities for Years Ahead. In Financial Times, 23 March 2006.

Davies, S. (2008). Contracting out employment services to the third and private organisation: A critique. Critical Social Policy, 28(2), 136-164, Sage Publication. 
EC (2019). Eurobarometer 493, Discrimination in the EU in 2019. https://ec.europa.eu/ commfrontoffice/publicopinionmobile/index.cfm/Survey/getsurveydetail/surveyky/2251.

EC (2020). A map of social enterprises and their eco-systems in Europe, Country report Slovakia. https://ec.europa.eu/social/main.jsp?Catid=1307\&langid=en.

IFP (2019). National Reform Program 2019, Ministry of Finance of the Slovak Republic. https://www.mfsr.sk/sk/financie/institut-financnej-politiky/strategicke-materialy/ narodny-program-reforiem/narodny-program-reforiem.html.

Hutter, B. H. (2006). The Role of Non-State Actors in Regulation, The Centre for analysis of risk and regulations, An ESRC Research Centre, Discussion paper 37.

Kalužná, D. (2008). Main Features of the Public Employment Service in the Slovak Republic. OECD Social, Employment, and Migration Papers No. 72, http://www.olis.oecd.org/ olis/2008doc.nsf/Linkto/delsa-elsa-wd-sem(2008)9.

Kuddo, A (2009). Employment Services and Active Labor Market Programs in Eastern European and Central Asian Countries, SP Discussion Paper, No. 0918. The World Bank Human Development Network Social Protection Team.

Macmillan, R. (2010). The third sector delivering public services: an evidence review, Third Sector Research Centre, Working Paper 20.

Mair, J., \& Martí, I. (2009). Entrepreneurship in and around institutional voids: A case study from Bangladesh. Journal of Business Venturing, 24(5), 419-435.

OECD (2012). Activating Jobseekers, How Australia Does It, OECD Publishing. http:// dx.doi.org/10.1787/9789264185920-en.

Polačková, Z. (2018). Disability and the labour market is Slovakia. In M. Štefánik et al. (eds), Labour Market in Slovakia 2019+. SAV.

Polačková, Z. (2019). Ludský kapitál ako faktor konkurencieschopnosti a rozvoja regionálnych celkov v SR a v Európe - súčasný stav a prognózovanie budúceho vývoja, Dissertation thesis. Slovak Technical University.

UPSVaR (2019) Statistical report of December 2019. https://www.upsvr.gov.sk/buxus/ generate_page.php?Page_id=855042. 